\title{
CULTURE'S EFFECT ON STUDENTS' ATTITUDES TOWARDS SCIENCE
}

\author{
Funda Örnek \\ Kocaeli, Turkey
}

\begin{abstract}
Cultural influence plays an important role in the association of attitudes towards science, this varies between countries because cultural context, including linguistic, social, political, economic, philosophical and religious aspects, determine and shape attitudes towards science. Cultural influence is the way we view the world. Learning, therefore, cannot be separated from its socio-cultural context (Vygotsky, 1987). Students carry their attitudes towards science into the classroom based upon their socio-cultural background influence. For example, Asian students choose a science predominantly even though science-based careers are less economically profitable because of their families' important impact on their choice and science-related choices have a very great prestige within the Asian cultures. Whereas students within the western cultures are individualist and make attractive choices reflecting their personal enjoyment and skills to a more considerable effect. Moreover, in Turkish culture, science-related careers also have a great prestige and have been perceived as very important for the country's development and therefore students' attitudes towards science is very positive even though their performance on the PISA is lower than average. As a result of different cultures holding different attitudes towards science and science-related careers, there is a great impact upon student uptake of science and sciencerelated careers.
\end{abstract}

Key words: career choice, Christianity, culture, family influence, Islam, religion, science attitudes, science.

\section{Introduction}

Investigating students' attitudes towards choosing, studying science and sciencerelated careers have been a fundamental focus on science education community for more than 40 years since there is a significant decline in students' interest to pursue sciencerelated careers. In addition, the numbers of students in middle and high schools turning away from science courses have increased (Zacharia \& Barton, 2004; Atwater, Wiggins, \& Gardner, 1995; Ayers \& Price, 1985; Cannon \& Simpson, 1985; Haladyna \& Shaughnessy, 1982; Hill, Atwater, \&Wiggins, 1995; Hofstein \& Welch, 1984; Simpson \& Oliver, 1990). This decrease will impinge on societies' economic and technology development because a knowledge-based economic future and advanced information society depend on an energized knowledge in science, math and engineering. For this reason, contemporary science education emphasizes engaging students in science so that more positive attitude towards science and science-related careers can be developed, because attitudes towards science can be considered to affect learning science (Lee \& Erdogan, 2007). Accordingly, to increase enrolment in science courses, augment science achievement, and encourage young 
people, especially in primary, middle, and high school, to pursue science-related careers, more positive attitudes towards science can be an influencing aspect. For example, schools in most OECD (Organisation for Economic Co-operation and Development) countries do a reasonable job in transmitting science knowledge and skills, but they fail to engage students in science and science-related careers which can be a hindrance for tomorrow's sciencebased societies (OECD, PISA, 2006). In other words, the decline in the number of science students has raised as a vital concern with regard to each nation's economic future. This future can only be attained by increasing the uptake of science and science-related subjects. Otherwise, the negative attitudes towards science and science-related subjects pose a really serious threat to economic prosperity (De Boer, 2000).

How can more positive attitudes towards science and science-related careers be established? It is not that easy to answer this question because there are several external factors that can affect students' attitudes towards science and science-related careers in either a positive or negative way. On the other hand, a broad range of research has been conducted to focus on students' attitudes towards science and science-science related careers to understand the nature of the problem and to remediate the problem (Osborne, Simon, \& Collins, 2003). These factors that influence students' attitudes towards science are mainly classroom (learning) environment, quality of teaching (teacher) in science courses, peer influence and parental influence on young students' science attitudes, the influence of gender on science attitudes, and the influence of culture and ethnicity on science attitudes (Collins, Michael, \& Simon, 2006; Jinks \& Morgan, 1999). This chapter seeks to emphasize the cultural influence on students' attitudes towards science and science-related careers.

\section{Cultural Influence}

Cultural influence has a significant effect on students' attitudes towards science and science-related careers such as medicine, forensic science, agriculture and so forth among different countries. Cultural context has several components that determine and shape young people's attitudes towards science and even their achievements in science. These components consist of elements such as linguistics, social, political, economic, philosophical, and religious aspects. Evidently, cultural attributes are associated with organizational hierarchy, needs and beliefs of people, and even family influence. Furthermore, gender effect on science attitudes can be also considered a part of cultural attributes because socio-cultural influence plays an important role for males and females to establish either a positive or negative attitudes towards science. For example, in Turkish culture, there is no difference between male and female's uptake in any careers in science or science-related professions. Thus, gender influence and cultural influence on students' attitudes towards science and science-related careers can be intertwined.

Culture persuades the way we view and experience the world. According to Vygotsky (1987), social context has a major influence on how we think and how we view the world. Culture constitutes the social context, providing many of the views with which we see the world. Learning cannot be separated from its socio-cultural context. Therefore, sociocultural background influences students' perception of science, achievement in science, and attitudes towards science and science-related careers or subjects. For example, as stated in the abstract Asian students choose science predominantly even though science-related 
careers are less economically profitable because of their families' important affect on their choice and science-related choices have a very great prestige within the Asian cultures. In addition, in Turkish culture, science-related careers also have a great prestige and students' attitudes towards science is very positive even though students' performance on the PISA (Programme for International Student Assessment) is lower than average (PISA, 2006). In PISA 2006, more than 400.000 students from 57 countries took part. Science was the first focus, but it also included reading and mathematics. Data were on student, family, and institutional factors to explain difference in students' performance. Whereas students within the western cultures such as in Europe, the USA, etc. are individualist and make attractive choices reflecting their personal enjoyment and skills to a more considerable effect.

Moreover, in African culture, social-cultural background of students impacts negatively on students' attitudes towards science (Kesemang \& Taiwo, 2002) because they possess unscientific knowledge that is opposite to their cultural beliefs such as taboos, omens, and witchcrafts. Consequently, different cultures impact differently upon science and science-related selection.

In addition, socio-cultural factors have an impact on students' achievement in science as well as their attitudes towards science because they come to class with their naïve or intuitive views of science not as blank boxes. Their background affects their learning of science and hence their attitudes towards science and science-related career choices.

\section{Influence of Family on Attitudes towards Science}

Families are the core of the culture. Families raise their children with their cultural essences so culture is embedded into children's lives. Therefore, family has a significant influence on students' choice whether these families are liberal families or authoritarian families. In both cases, families strongly influence students' attitudes towards science and science-related choices in either a positive or negative fashion. In many studies, it has been found that there are positive relationships between children's attitudes towards science and science-related choices and parents' attitudes towards science and science-related careers (Talton \& Simpson, 1985; Talton \& Simpson, 1986; Breakwell \& Beardsell, 1992; Osborne, Simon, \& Collins, 2003). For example, the majority of parents in Turkey have positive attitudes towards science and science-related choices and support their children-whether they are male or female e.g. to choose a physics teacher as their profession (Erjem, 2000).

Parental influence can be from father's positive attitudes towards science, a mother's support and encouragement of science, authoritarian or liberal family influence, and general family encouragement. As a part of the author's ongoing research to investigate science educators and math educators' views and observations regarding the influence of culture on students' attitudes towards science and science-related career choices, online interviews conducted with several university professors in Science Education and several teachers (physics, science, mathematics) in Turkey and other countries to have their conceptions with regard to Turkish culture's and other cultures' influence on students' science attitudes and their choice in science-related careers. The following quote from one professor in Amasya University explores the influence of parents on students' attitudes towards science: 
"I would like to think a family as a culture because a child is immersed with the culture in the family-the way a child is raised, values, ethics, and religion. To say whether parents have positive or influence on their children's attitudes towards science, it is important that we need to look at the relationships between mother-child, father-child, mother-father and child. It is possible to have different kinds of family structures such as authoritarian, liberal, and careless families. In Turkish culture, father is most dominant in the family. Based on father's education level, children can have either positive or negative attitudes towards science and science-related careers. In our country, many studies showed that father's education level most influences 15 years old students' attitudes towards science." (Professor in science education, Amasya University, Turkey, February 2010)

"I think the culture is very important, and most of the influence comes from the home life. If you are growing up around parents who value science, and encourage it, then so will you. Probably why private schools always have large science departments. so definitely the culture and home life, role models are massive factor." (Former science teacher in the UK, February 2010)

In addition, based on PISA 2006 results, in some European countries such as Ireland, France, Belgium, and Switzerland, students with a more advantaged socio-economic background were more likely to show a general interest in science. Along with this, one very significant feature of a student's background is, if they have one parent in a sciencerelated career. As a result, the parent's attitudes towards science and science-related careers are positively related to their children's attitudes toward science and science-related career choices (Kalender \& Berberoglu, 2009).

Authoritarian families from certain cultures, coming mostly from the lower to moderate social status, have more positive attitudes towards science and science-related choices, whereas liberal families, who may have higher socio-economic status, have less positive attitudes towards science and science-related careers. Of course, this varies from culture to culture. For example, in western countries, children are raised more liberally that it does not matter whether they belong to lower socio-economic status or higher socioeconomic status. Liberal families in general are in favor of individualistic decisions of their children so they will not try to persuade their children's career choices. These parents support their children with regard to their careers which may be based on their enjoyment or abilities. Breakwell \& Beardsell (1992) explored that more liberal parents' children had less favorable attitudes towards science because of their influence on their children. These parents supported sex equality and encourage their children in political participation. In general, participation in political endeavors is more likely from social sciences. In addition, they pointed out one important potential reason why liberal families' children are more likely not to choose science or science-related choices. This liberalism probably leads to children choosing more art-related careers. In these subjects, probably the effect of science in the environment is more emphasized and as a result of it, it may lead to students having negative attitudes towards science because science damages our environment where we live in such as nuclear power reactors. They do not portray other ways that science can solve the problems related to the environment. This happens, in most cases, especially in developed countries because these countries are at a very high level in terms of technology and science even though their citizens are more likely to hold negative attitudes towards science. This 
leads to recruitment of professionals or students to work in the technology industry, from abroad. For example, it is not surprising to see mostly Asian students (of course, there are also students from other countries) in physics departments in the universities of the USA or Indian students in computer engineering and computer science departments. In other words, there have been a significant number of originally non American science students, scientists, and technologists participating in the development of science and technology of the USA (Haidar, 2002). Therefore, many citizens do not feel or think that science is very important to the development of their country as they perceive their country is already at a very advanced technological level. On the other hand, there is a need to establish positive attitudes towards science and science related careers and promote science in nationwide such as organizing Science, Math, and Technology festivals.

Considering developing countries, Turkey is one of the developing countries that science-related careers also have a great prestige and have been perceived as very important for the country' development and students' attitudes towards science is very positive even though students' performance on the PISA is lower than average as shown in Figure 1.

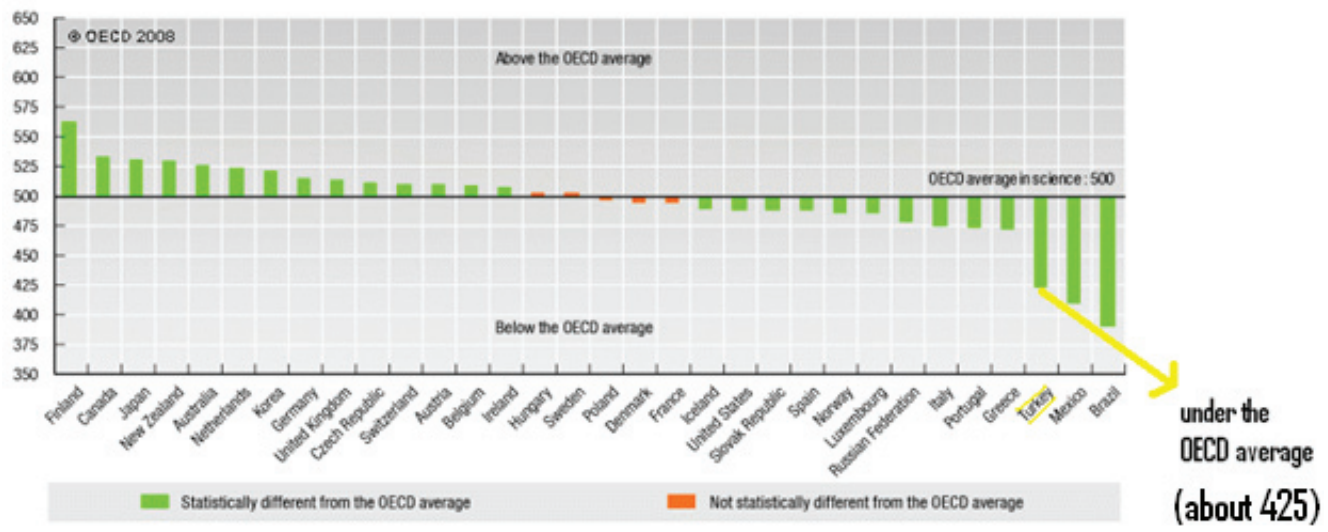

Figure 1: Performance (mean scores) on the science scale in PISA 2006 (OECD, PISA, 2006).

As is seen in Figure 1, performance of Turkish students on the science scale in PISA $(\sim 425)$ is lower than OECD average in science (500). It is interesting to see a negative correlation between students' attitudes towards science and science-related careers and their performance on the science in PISA. From the point of view of a professor in science education in Turkey, he explains this amazing contrast as follows:

In Countries, which have higher scores in PISA and TIMMS (The Trends in International Mathematics and Science Study), GDP (The gross domestic product) is high, technology is well-established, and there is no civil war. Therefore, in our country and in most countries in the world, based on the research results, it has been found that science and technology have an important place for students. In many countries, including Turkey, science and technology have been seen as an important factor for countries' development because a knowledge-based economic future and advanced information society depend on an energized knowledge in science, math 
and engineering, science and technology can help us to find treatments for health problems such as cancer, AIDS, etc., and to find solution for environmental problems such as air and noise pollutions, nuclear waste, and etc. consequently, students are aware of understanding of the importance of science and students think advances in science and technology usually bring social benefits and important influences on everyone's life. Whereas in developed countries, technology is developed and students have most likely less interest in science and technology. This shows that there is a satisfaction of technology. Along with this, developing and underdeveloped countries, especially countries in Africa, people have an incredible interest in technology and of course this is related to science. Therefore, in those countries people are more interested in science and technology." (Professor in science education, Amasya University, Turkey, February 2010).

As is explained by the professor, children's interest in science and technology is related to their understanding of importance of science and technology. This awareness in general is given by parents. In addition, it is very important for families that their children study science and science-related careers in Turkey because they think if their children succeed in science and math that shows their children are very smart so that they are proud of their children. This factor forces students to choose science or science-related careers, especially in authoritarian families. In society, science and science-related careers have prestige as well. The following quotes from a mathematics teacher and a professor in physics education in Turkey explore this as follows:

"Parents always think that if their children succeed in Science, then they are certainly smart, successful, and outstanding because science, especially physics is a very difficult subject and it is not easy to be successful in science." (Math teacher in private teaching institute, Turkey, February, 2010).

"In Turkey, science and science-related careers are popular, especially in medicine because it is easy to get a job after graduation and it also has important status in the society even though it takes a long time (at least 6 years if they do not continue to do TUS-Basic Medicine points in Examination of Specialization in Medicine) to become a doctor. Students should do well in science, especially chemistry and biology, physics is of course required, especially when students study on oncology or medical physics, but for basic knowledge of medicine the former ones are definitely required." (Professor in physics education, Turkey, February 2010).

In summary, the most significant impact upon students' attitudes towards science and science-related career choices correlates to that of the parents'. This influence can be in either positive or negative way. For example, Asian students prefer to study science-related careers such as medicine-related studies (Taylor, 1993; Modood, 1993; Osborne, Simon, $\&$ Collins, 2003) because Asian families greatly influence on their children career choice (Woodrow, 1996) as well as Turkish families (Erdemir, 2004). 


\section{Influence of Religion on Attitudes towards Science}

Religion is a part of culture and has values, beliefs, and norms. It also has an important influence on students' attitudes towards science and science-related career choices. These attitudes can be either positive or negative based on how much the society wants to merge religion with science. In addition, it depends on the interpretation of the holy books in different religions such Qur'an in Islam or Bible in Christianity. So, people's worldviews vary with their religious background. The author will consider the two religions to explain the major influences that religion may have on people's ways of thinking about science and science-related career choices. Of course, there are other religions that may impact on people's ways of thinking about science and science-related career professions. It is unfortunate that science and religion are perceived as two different entities (Guessoum, 2009) and there has always been a conflict between the two, whereas science and religion could work together in harmony. For example, Islam and science had worked in harmony until Ottoman Empire was destroyed (early 1900s). Hüseyin Hilmi Işık (2001), a scientist (Pharmacist and Chemical Engineer who synthesized and determined a formula for the ester "phenylcyannitro-methan-methyl") was also an Islamic scholar, stated "...Islam was misrepresented as hostile towards knowledge, science, as hostile towards knowledge, science and bravery, while, in fact, it is the protector of such things, encouraging every kind of progress and improvement. "(p. 12). Because of misrepresentation of Islam, as stated by Işı1k (2001), countries with Muslim populations lost some of their understanding contemporary knowledge in science, which is one of the most important requirements of the 21 st century. To develop and maintain a literate citizenry, science is a fundamental requirement. (Tobin, 2010). Within the Muslim world, it has proved difficult to sustain the accomplishments in science, math, and engineering and even in military defense, as there was been a prevalence to compartmentalize, and hence separate science and religion. This has caused people from these countries to fall behind in the knowledge of science, leading to a major obstacle in the development of said countries. A secondary global issue, as a result of this, is the negative image portrayed of the religion, as Islam is often labeled as the culprit (Iş1k, 2001). Thus, students may have negative attitudes towards science and science-related careers choices such as genetics, medicine, and physics. He stated; “... we have to abolish this black curtain and get rid of the oriental religion...” (p. 13). Then, positive attitudes towards science and science-related career choices can be granted. Even in history, the most famous scientists such as Newton, Kepler, and Leibniz were very religious and followed their religions tightly (Iş1k, 2001).

For example, Isaac Newton (1642-1727), who was a physicist, mathematician, astronomer, philosopher, and theologian, was one of the most prominent people in the history. Besides his scientific fame, Newton, it was also noteworthy that he studied the Holy Bible. Newton's best-known discoveries were the laws of motion and universal gravitation. Newton's laws of motion are composed of three laws: 1) Newton's first law of motion states; "an object moves in a straight line and at constant speed except to the extent that it interacts with other objects." (Chabay \& Sherwood, 2002, p. 19). It is also known as the

law of inertia. 2) Newton's second law of motion states that $\frac{d \vec{p}}{d}=\vec{F}_{n e t}=\frac{d(m \vec{v})}{d}=m \vec{a}$. 
3) Newton's third law of motion states that the force that object A exerts on object B is equal and opposite to the force that object B exerts on object A. It is also called "reciprocity".

Newton's law of universal gravitation states; "the force $F_{g}$ acts along a line connecting the two objects, and its magnitude is proportional to the mass $m_{1}$ of the first object and to the mass $m_{2}$ of the second object, and inversely proportional to the square of the distance $r$ between two objects. "(See Figure 2) (Chabay \& Sherwood, 2002, p. 38).

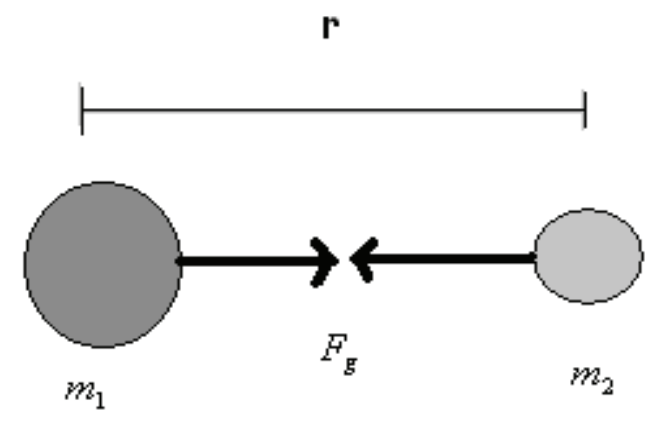

\author{
The Gravitational Force Law
}

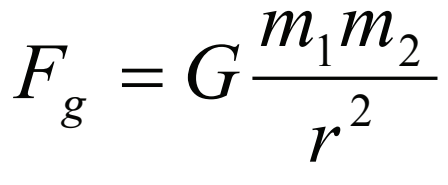

G: constant

\title{
Figure 2: The gravitational force.
}

After his discoveries, he said; "Gravity explains the motions of the planet, but it cannot explain who set the planets in motion. God governs all things and knows all that is or can be done." (Dao, 2008). Source is changed. As is explained, science and religion were exactly parallel with each other in those days. Science and religion as parallel lines should embrace each other.

In Islam (mostly Arab culture is considered even though it does not relate to only Arab culture), modern science is not welcomed very well even in the Western world. Christianity has not embraced some of modern science, such as cloning, especially human cloning (Haidar, 2002) and theory of evolution. In Christianity, especially the Catholic Church opposes all forms of cloning because the concept of cloning is not consistent with the Holy Bible's view of human life. It was stated; "Human cloning is intrinsically illicit.... From the ethical point of view, so-called therapeutic cloning is even more serious. To create embryos with the intention of destroying them, even with the intention of helping the sick, is completely incompatible with human dignity." (Pullella \& Lewis, 2008). On the other hand, the prohibition of cloning will limit scientific progress. According to scientists, to ban cloning for especially medical research may limit scientific progress. Moreover, researcher and scientists believe; "stem cells taken through cloning are useful for treating several diseases, such as diabetes and Alzheimer's, because the resulting tissue could be genetically matched to a patient's body, avoiding immunological rejection." (Brainard, 2003). Therefore, this banning due to the influence of religion will impact people's attitudes towards science and science-related careers. 
Here is one example from the author's research about teacher candidates' views of Nature of Science conducted with Arab science teacher candidates while they were doing their PGDE-Post Diploma Graduate Education. The results were presented in the CRPP conference-Centre for research in Pedagogy and Practice in Singapore in 2009. The following quotes demonstrate that Science teacher candidates' attitudes towards science, especially genetics are not positive because they think it is against the teaching of Islam.

"I agree that science is infused with social and cultural values because science is related to cultural, and social and philosophical assumption, we are Muslim and the knowledge required in Islam but we must take in mind the legitimacy term for example genetic science is important in science but we cannot use all application like cloning in human or animals because it is interference of God's creation. "(Science teacher candidate 1, Fall 2008).

"Science should be universal, but some time it affected by the culture for example non-Islamic world can use science to make cloning but it's not acceptable to the Islamic world." (Science teacher candidate 2, Fall 2008).

On the contrary; Islam is a religion which encourages all aspects of knowledge, all aspects of science and all aspects of experimentation (Iş1k, 2001). Therefore, one would expect Muslims to be in favor of science and encourage their fellows to carry out experiments in science. Işı (2001) affirmed; "Islam is a dynamic religion commanding us to study science, experiment and to do positive work." In many places of the Islamic holy book, the Qur'an, human beings are commanded to see and observe nature, which includes all creatures, living and lifeless beings. Here is an example from the days of the Prophet (571-632) which illustrates how important it is to do experimentation in Islam.

'One day his As-hâb-ikirâm 'alaihim-ur-ridwân' (friends of the Prophet) asked our Prophet, Some of us who have been to Yemen saw that they budded the date trees in a different way and got better dates. Shall we bud our trees in Medina as our fathers have been doing or as we have seen them do in Yemen, thus getting better and more plentiful dates?" Rasûlullah could have answered them, "Wait a bit! When Hadrat Jabrâil (Gabriel) comes, I will ask him and tell you what I learn," or "I must think for a while; when Allahu ta'âlâ lets my heart know the truth, I will tell you." He didn't. Instead, he said, "Try it! But some of the trees with your father's method, and others with the method you saw being used in Yemen! Then always use the method which gives better dates!" In other words, he commanded us to experiment and to rely on experimentation, which is the basis of science. He could have learned it from the angel or, no doubt, it might have materialized in his blessed heart. But he pointed out that all over the world Muslims who will exist until the end of the world should rely on experimentation and science. "(Iş1k, 2001, p36).

Because of misunderstanding and the misrepresentation of some concepts such as cloning and evolution in science, some families in Arab culture have negative attitudes towards science. As a result of their influence, their children also foster these negative 
attitudes towards science. When, in fact, cloning is not understood well enough to make informed comments on it, as is seen, in the above excerpts from some Arab science teacher candidates. The findings are sometimes conveyed in a way that people get confused and refuse the new invention because of conflict with their religious values that they believe in. As can be recalled, there was a very intriguing headline regarding cloning, saying that people created a sheep and they will create a human in media and newspapers. Whereas cloning is not creating a new thing, it is to produce of copies of DNA fragments (molecular cloning), cells (cell cloning), or organisms as explained in MedlinePlus.

Prof. Ramazan Ayvalli in Faculty of Theology (Educated in Egypt and Turkey) explained cloning from a religious point of view. Fertilizing an egg with sperm and providing a suitable environment for this fertilized egg is not the creation of something from nothing. It is like taking a picture of a person or an object or making a copy of something. Human being can make changes to already existing things. Therefore, it is not possible to create a human or even a fly. Human exists with their soul. The body of a human is like a carpenter's tools. Even if one's all organs are replaced with different people's organs, the person's mind, thinking, intelligence, and knowledge are not going to be changed. In other words, carpenter's old tools are replaced with new tools. As changing tools, knowledge and talent of carpenter do not change. For example, if a blind person has eye transplantation, then $\mathrm{s} / \mathrm{he}$ may see. Even if one's blood, brain, heart are changed, this change does affect their thinking. Healthy organ functions well and human means soul. Theoretically, humans can be copied, but souls cannot be copied. Soul is not related to genetic makeup. Each living being has a different soul. Moreover, souls of identical twins are different.

Even if a famous person is copied; the baby from cloning will have different knowledge, thinking, intelligence, and abilities from that famous person. Let's say you want to have many scientists like Einstein to have his brain to solve many problems regarding physics, and you have him genetically copied. The babies will have the same appearance as Einstein, but not his thinking, his intelligence, knowledge, and brain functions because the new babies will have their own psychological conditions and they will have different life experiences to him.

As scientists explained, either mother or father is not a part of cloning. If genetic character comes from the mother, then the mother's chromosomes are mixture of her own parents' chromosomes. Therefore, foetus carries her/his grandmother's and grandfather's chromosomes and not only his/her own mother. A problem with regards, this causes disposition for a race. For this reason, human cloning can be harmful.

Prof Ayvalli stated that, in some newspapers and media, there are headlines such as 'human created a sheep' or 'human is creating a human'. Cloning is not equivalent to creating as creating is making something from nothing. In cloning, genetic substances inside a cell which is created by Allah is used. These substances are injected into the mother's egg. The soul is given by Allah. This cannot be called creating. It is like making a sweet by mixing flour, sugar, and oil. Flour, sugar, and oil cannot be created from nothing. However, a new product can be produced by using available substances. In cloning, only physical characteristics are copied. For example, identical twins have similar DNA characteristics, that's; their physical characteristics are similar, but the souls are different.

It is beneficial to rear animals to produce better quality meat, milk, eggs and is not against Islam. Moreover, married couples who cannot conceive babies in naturally, genetic 
material from the father would be injected into the mother's egg which would then be implanted into mother's womb to grow. If it is not harmful for human health to eat cloned animals such as sheep, it is not right to be against animal cloning.

Italian Prof. Dr. Severino Antinori, who works in cloning stated that cloning is not like photocopying. We do not produce the same people. Copying of a body can be done, but the person's psychological conditions cannot be copied. Therefore, a person with the same soul cannot be copied.

As is explained by Prof. Severino Antibori and Prof. Ramazan Ayvali, there is no conflict between religion and science because cloning is not creating something that does not already exist. So understanding that science and Islam can work in harmony should have a positive influence on both families' and children's attitudes towards science, as they will see that Islam encourages human beings to study science, do experimentation for the purpose of human well-being. The religion emphasizes that people should trust in science and experimentation to obtain the best results for society's prosperity.

One of the reasons that Turkish students choose science or science-related careers to study is that their religion, Islam, influences their choices. They follow what Islam says about the science and the importance of science in our life. Without science, the country cannot be developed and provide the necessary social benefits to its citizens. They believe that they lost knowledge of science and the need to seek knowledge of science and bring it to their countries. In fact, students follow these two hadithes of the Prophet, which state: "Hikmat (that is science and art) is the lost property of the Muslims. Let him take it wherever he finds it!" and "Seek knowledge of science even in China!" (Iș1k, 2001). (A hadith is the words and deeds of the Islamic prophet). The following quotes from a physics teacher and a science teacher in Turkey reinforce the above statement more. Excerpts were collected from the research based on a qualitative framework on how culture influenced students' and experts' attitudes towards science. Volunteers were interviewed via phone or online chat programmes.

"Even though the influence of culture on students' attitudes towards science has been decreasing in the globalized world and we are establishing same thinking with the western world, our religion is still taking a part of students' life as Turkish culture. Therefore, students still follow the hadith of our prophet saying "Seek knowledge of science even in China!" and they chose to study science. Moreover, they leave their countries to study broad and return to their country to serve to the country to develop our country. Their goal is to produce resources for Turkey. These students are mostly from a low socio-economic level and very determined. They are mostly a grandchild of martyr in the war and they are aware that their country cannot be protected by weapon instead, knowledge-based economic development. S/he knows that knowledge-based economic future and advanced information society depends on an energized knowledge in science, math, technology, and engineering." (Science teacher, Turkey, February 2010).

"Religion of Islam is the major religion in Turkey and science in Islam is very important because Islam is against to not being educated. As known, religion affects culture of a country. Religion and culture are very much related, so I can say that people have positive attitudes towards science through an effect of religion. Families 
always want to raise children in a way to serve to their country to develop the country. In addition, families want their children to provide knowledge-based economic future and advanced information society for the country. Therefore, Turkish culture has a positive influence on students' and families' attitudes towards science."(Physics teacher, Turkey, February, 2010).

In summary, religion can have a potential positive or negative effect on people's attitudes towards science and science-related careers. As most researchers point out, students, who consider science and religion in conflict with each other in terms of seeking knowledge, do not have any improvement on the nature of science views (Mugaloglu \& Bayram, 2009; Abd-el-Khalick \& Akerson, 2004; Roth \& Alexander, 1997). The religious values of students or even professionals are in fact a significant predictor towards students' attitudes with regards science and they can establish negative attitudes towards science because they think some topics or concepts are not appropriate for religious values. So there is always a potential interference between students' religious values and their attitudes towards science, even though their understanding of these controversial concepts has flaws as explained above regarding cloning.

\section{Influence of Superstitions on Attitudes towards Science}

Superstitions are a part of culture and have a significant effect on people's lives including personal and professional lives. Superstition is a credulous belief and is not based on reason, knowledge, experience, or observation. It is mostly known as 'folk beliefs' or 'old wives tales'. It is in general related to beliefs and practices such as luck (bad or good), prophecy, and spiritual beings. There is no rational behind this type of beliefs that can affect future events as the superstition would have and believe (Foster \& Kokko, 2009). For example, here are two common examples regarding superstitions: If a black cat crosses a parson's pathway, this is bad luck or it is good luck when a ladybug lands on a person.

In addition, some superstitions come from religious practices and people continue to observe these superstitions even though they do not adhere to any religion. In general, these practices lost their original meanings in this transition. In some cases, the practices are adapted to the current religion the people practice. For instance, pagan symbols to protect against evil were replaced with the Christian cross during the Christianizing of Europe.

Superstitions are socio-cultural factors that play a significant role in science learning of children and their attitudes towards science in mostly non-western cultures such as African culture. Of course, many superstitions take place in other cultures but not to the degree of impact which superstitions have as in African culture. For example, there is a cultural conflict between the scientific culture and African, African-American, Native American cultures (Lemke, 2001; Allen \& Crawley, 1998; Aikenhead, 1996; Cobern, 1996; Costa, 1995; Barba, 1993). Moreover superstitions took place, especially in rural parts of Turkey before 1990s in Turkish culture. It was unfortunate that these beliefs were embedded in the religion so these beliefs affected students' science learning, students' attitudes towards science, and their science-related career choices. A physics teacher in Turkey says "because unfortunately, students who had a low socioeconomic background in rural areas had nonscientific beliefs as a part of the religion, their attitudes towards science and science learning were negative 
so that they did not choose to study science for their further endeavours."

In African culture, superstitions impact negatively on students' learning of science (Kesemang \& Taiwo, 2002). Several African educators found out that the impact of social-cultural factors impact African children's attitudes towards science and even their achievement in science (Kesemang \& Taiwo, 2002; Ogunniyi, 1988; Jegede \& Okebukola, 1991). Researchers and educators point out that children's socio-cultural background may be a barrier to their productive learning of science. It will definitely affect their thinking skills and process. For example, as is shown in Kesemang \& Taiwo's study regarding Botswana culture, in most African culture, children do not believe that people die of natural causes such as cancer, or AIDS. They believe that a person dies because of witchcraft. Children believe that the death of person is due to bewitching by a relation, an enemy of the person's family, a witch doctor, or a traditional medicine person. As an example from Nigerian culture, people consider the chameleon to be evil. Another very interesting example relates to lightning; when a person is struck by lightning, it is believed that that a witch doctor or an evil medicine man or woman is responsible for that person's death. Therefore, the child has been raised with the influence of non-rationale beliefs surrounding them including beliefs about natural phenomena such as lightning and thunder. Children's thinking is shaped and dominated by these beliefs.

Moreover, children in African culture believe that the products of science and technology such as aeroplanes, electricity, and so forth are the white man's magic. Children raised in African culture are affected by these beliefs so that their attitudes towards science and their achievement in science learning are negatively influenced (Kesemang \& Taiwo, 2002). This does not mean that all people in African culture have only negative attitudes and their achievement in science is low. There are many African people who are majors in science or scientists, but they may retain their cultural knowledge in synchronization with their scientific knowledge. These people may be able to study modern ecology view the chameleon is evil (Cobern, 1996). However, these people often hide their beliefs in cultural knowledge when they are with other people who are not raised in the African culture. Here is a quotation from an African professor in educational psychology who was educated in both Africa and Canada and taught in Africa and Bahrain, he explores the influence of superstitious beliefs including religion on students' attitudes towards science.

“... Causation system among modern African students influenced by both the Western scientific paradigm and African indigenous world views, and in addition influenced by Christianization and Islamization. Causation among students in African is multidimensional and it would be difficult for me to point at any single factor without research to see which of these variables factors influence African students' attitudes towards learning science. From ordinary observation need also to consider the level of acculturation, education and religious influence in particular African communities. When you unpack all these causation factors, you might find four examples that typically rural students (with a strong rural background so called SRB) love to learn science, but tend to be influenced by superstitious beliefs that conflict with scientific reasoning- Then there certain religious sects with strong beliefs conflicting with scientific knowledge. (Professor in Educational Psychology, Bahrain, February 2010). 
As a result, cultural beliefs-taboos, omens, or witchcrafts held by students affect negatively on their science attitudes and science achievement. Here are some examples for taboos, omens, and witchcrafts. 'Water or fire should not be brought into (one's) compound at night' is an example of taboos. 'When cocks fight, it is a sign that there will be a visitor to one's compound later on that day' is an example of omens. Finally, 'When a person dies of AIDS-related ailments, $\mathrm{s} /$ he is generally said to have been 'bewitched' during burial rites' is an example of witchcraft. For example, in Jegede \& Okebukola (1991) study, they found that traditional African beliefs-taboos, omens influence students' science learning. The conflict between traditional culture and scientific culture causes that students have unfavorable attitudes towards science (Jegede \& Fraser, 1989). However, it is important to remember that African students can hold a traditional African view as well as a scientific view and they can have positive attitudes towards science and science learning.

\section{Summary}

This chapter has sought to provide a review of cultural influence on students' attitudes towards science and science-related career choices, including some interviews with experts in science and mathematics education of ongoing research of the author. As is elucidated in this chapter, cultural influence on students' attitudes towards science and science-related career choices plays a significant role and affect their future choices. The influence of culture is explained in three sub-categories which are the influence of families, the influence of religion, and the influence of superstitions on students' attitudes towards science and science-related career choices. Their influences can be either positive or negative based on the culture of societies. As the author pointed out, all research done so far has shown that different societies hold different perspectives on science and the value of science-related careers such as genetic engineering, medicine, and agriculture. For example, Asian students prefer to study for degrees in science related careers such as medicine-related studies, engineering, or even mathematics probably because of parental involvement. On the contrary, Afro-Caribbean students do not choose to study science or science-related studies; instead they prefer to pursue degrees in the social sciences (Osborne et al., 2003) such as history, economics. Many students' attitudes towards science are influenced by their parents because they want to please their parents even though students may not be fond of science. Therefore, parental involvement has a major role in influencing their children's attitudes towards science, advising, and guiding their children's career choices (Collins, Michael, \& Simon, 2006).

Religion also has a big influence on students' attitudes towards science and sciencerelated choices because mostly the message of the religion is conveyed to society in an obstructive way. This is especially happening in Islam because discussions of science and Islam continue and this prevents both students and families from having positive attitudes towards science and studying science or science-related career degrees as explained by the author. For example, it is very obvious that in today's world, the majority Muslim countries' contributions to science are negligible (Edis, 2009). On the other hand, Muslim scientists in non-Muslim countries have significant contributions to science. Of course, Islam's influence on students' attitudes towards science is positive in some other countries such as Turkey. 
Cultural beliefs, including superstitions-taboos, omens, and witchcrafts impact negatively upon students' science learning, students' science attitudes, and their achievement in science because students come to the science class with cultural beliefs pre-occupied in their minds which can be opposite to what is known to be scientifically correct knowledge. Since their cultural beliefs are opposite to scientifically correct knowledge, they may not choose to study science-related careers. Therefore, there is an essential need to replace students' unscientific knowledge that they hold as a result of their cultural beliefs such as taboos, omens, and witchcrafts with scientifically correct concepts. For example, the unscientific concept that they have of 'lightning can be sent by a witch doctor to strike other people' should be replaced by the scientific explanation which is that it is briefly enormous electrical discharge caused because positive and negative charges are imbalanced. To attract students to science and science-related careers, traditional beliefs, culture and scientific culture should be linked in a way that students learn science and their science attitudes are influenced positively.

In conclusion, cultural difference, including family background, religion, and superstitions-taboos, omens, and witchcrafts is a significant aspect of many students' attitudes towards science and science-related career choices. In order to improve science education, attract, and retain more students to science and science-related subjects, the science educators, religious scholars, families, and policy makers need to identify successful ways that allow students to practice science and allow cultural border-crossing for students.

\section{Acknowledgement}

This paper was presented at $21^{\text {st }}$ Symposium on Chemistry and Science Education at the TU Dortmund University, Germany in 2012.

The author would like to thank Samina Shujaat (former science teacher) for her thoughtful comments on the draft version of this paper.

\section{References}

Abd-El-Khalick, F., \& Akerson, V. (2004). Learning as conceptual change: Factors mediating the development of preservice elementary teachers' views of nature of science [Electronic version]. Science Education, 88 (5), 785-810.

Aikenhead, G.S. (1996). Science education: Border crossing into the subculture of science. Studies in Science Education, 27, 1-52.

Allen, N. J., \& Crawley, F. E. (1998). Voices from the bridge: Worldview conflicts of Kickapoo students of science. Journal of Research in Science Teaching, 35, 111-132.

Atwater, M., Wiggins, J., \& Gardner, C. (1995). A study of urban middle-school students with high and low attitudes toward science. Journal of Research in Science Teaching, 32, 665-677.

Ayers, B., \& Price, O. (1985). Children's attitudes toward science. School Science and Mathematics, 75, 457-460.

Barba, R.H. (1993). A study of culturally syntonic variables in the bilingual/bicultural science classroom. Journal of Research in Science Teaching, 30, 1053-1071.

Brainard, J. (2003). Cloning debate moves to the states. The Chronicle of Higher Education, 49 (29), A22-A23. 
Breakwell, G. M. \& Beardsell, S. (1992). Gender, parental and peer influences upon science attitudes and activities [Electronic version]. Public Understanding of Science, 1, 183197.

Cannon, R., \& Simpson, R. (1985). Relationships among attitude, motivation, and achievement of ability grouped, seventh grade, life science students. Science Education, 69, 121138.

Chabay, R. W., \& Sherwood, B. A. (2002). Vol I: Matter and interactions: Modern mechanics. New York: John Wiley \& Sons, Inc.

Cobern, W. W. (1996). Worldview theory and conceptual change in science education. Science Education, 80, 579-610.

Cobern, W. W. (1996). Traditional culture and science education in Africa: Merely language games? A paper presented at the meeting for Traditional Culture, Science and Technology, and Development: Toward a New Literacy for Science and Technology Tokyo Institute of Technology, Meguro-ku, Tokyo, Japan.

Collins, S., Michael, R., \& Simon, S. (2006). A literature review of research conducted on young people's attitudes to science education and biomedical science (The Welcome Trust). London, UK: Institute of Education, University of London.

Costa, V. B. (1995). When science is another world: Relationships between worlds of family, friends, school, and science. Science Education, 79, 313-333.

Dao, C. (2008). Man of Science, Man of God: Isaac Newton. Acts \& Facts, 37 (5), 8.

De Boer, G. (2000). Scientific literacy: Another look at its historical and contemporary meanings and its relationship to science education reform [Electronic version]. Journal of Research in Science Teaching, 37, 582-601.

Edis, T. (2009). Modern science and conservative Islam: An uneasy relationship [Electronic version]. Science and Education, 18, 885-903.

Erdemir, N. (2010). Fizik öğretmeni adaylarinin bölümü tercih nedenleri ve mekanik başari düzeylerine etkisi. Erzincan Egitim Fakultesi Dergisi (in press).

Erdemir, N. (2004). An identification of physics student teachers' changing of successes and attitudes in their education processes. Science Institute, Black sea Technical University, Unpublished Doctoral Dissertation, Turkey.

Erjem, Y. (2000). Öğretmenlik mesleğine yönelmede ailenin İşlevi, öğretmenlik meslek bilgisi Programına katılan Öğrenciler Üzerine bir araştırma, Çukurova Üniversitesi eğitim Fakültesi Dergisi, Cild: 2 Sayı 19.

Foster, K. R., \& Kokko, H. (2009). The evolution of superstitious and superstition-like behavior [Electronic version]. Proceedings of the Royal Society B: Biological Sciences, 276, 31-37.

Guessoum, N. (2009). Science, religion, and the quest for knowledge and truth: An Islamic perspective [Electronic version]. Cultural Studies of Science Education, 5, 55-69.

Haidar, A. H. (2002). Emirates secondary school science teachers' perspectives on the nexus between modern science and Arab culture [Electronic version]. International Journal of Science Education, 24 (6), 611-626.

Haladyna, T., \& Shaughnessy, J. (1982). Attitudes toward science: A quantitative synthesis. Science Education, 66, 547-563.

Hill, G., Atwater, M., \& Wiggins, J. (1995). Attitudes toward science of urban seventh-grade life science students over time, and the relationship to future plans, family, teacher, curriculum, and school. Urban Education, 30 (1), 71-92. 
Hofstein, A., \& Welsh, W. W. (1984). The stability of attitudes towards science between junior and senior high school. Research in Science and Technological Education, 2, 131- 138.

Hofstein, A., Maoz, S., \& Rishpon, M. (1990). Attitudes toward school science: A comparison of participants and nonparticipants in extracurricular science activities. School, Science and Mathematics, 90 (1), 13-22.

Işık, H. H. (2001). Endless Bliss. First Fascicle. (12 ${ }^{\text {th }}$ Ed.). Istanbul, TURKEY: Hakikatkitabevi: Waqf Ikhlas Publications.

Işık, H. H. (2001). Endless Bliss. Second Fascicle. (10 ${ }^{\text {th }}$ Ed.). Istanbul, TURKEY: Hakikatkitabevi: Waqf Ikhlas Publications.

Işık, H. H. (2001). Endless Bliss. Fifth Fascicle. $\left(8^{\text {th }}\right.$ Ed.). Istanbul, TURKEY: Hakikatkitabevi: Waqf Ikhlas Publications.

Jegede, O. J., \& Okebukola, P. A. O. (1991). The relationship between African traditional cosmology and students' acquation of science process skills. International Journal of Science Education, 13, 37-47.

Jegede, O. J., \& Fraser, B. (1989). Influence of socio-cultural factors on secondary school students' attitude towards science [Electronic version]. Research in Science Education, 19, 155-164.

Jinks, J. L., \& Morgan, V. (1999). Children's perceived academic self-efficacy: An inventory scale. Clearing House, 72, 224-230.

Kalender, I. \& Berberoglu, G. (2009). An assessment of factors related to science achievement of Turkish students [Electronic version]. International Journal of Science Education, 31 (10), 1379-1394.

Kesemang, M. E. E., \& Taiwo, A. A. (2002). The correlates of the socio-cultural background of Botswana junior secondary school students with their attitudes towards and achievements in science [Electronic version]. International Journal of Science Education, 24 (9), 919-940.

Lee, M. K., \& Erdogan, I. (2007). The effect of science-technology-society teaching on students' attitudes towards science and certain aspects of creativity [Electronic version]. International Journal of Science Education, 29 (11), 1315-1327.

Lemke, J. L. (2001). Articulating communities: Sociocultural perspectives on science education. Journal of Research in Science Teaching, 38 (3), 296-316.

Modood, T. (1993). The number of ethnic minority students in higher education. Some ground for optimism. Oxford Review of Education, 19, 167-182.

Mugaloglu, E. Z., \& Bayram, H. (2009). Do religious values of prospective teachers affect their attitudes toward science teaching? [Electronic version]. Turkish Journal of Science Education, 6 (3), 91-98.

OECD, PISA (2006). Retrieved March 28, 2009 from

http://www.oecd.org/document/40/0,3343,en_2649_34319_41689640_1_1_1_37417,0 $0 . h$ tml

Ogunniyi, M. B. (1988). Adopting Western science to traditional African culture. International Journal of Science Education, 10, 1-9.

Ornek, F. (2009). Bahrain teachers'candidates'views of nature of science: A phenomenographic study. Presented at The $3^{\text {rd }}$ Redesigning Pedagogy International Conference (CRPP) in Singapore.

Osborne, J., Simon, S., \& Collins, S. (2003). Attitudes towards science: A review of the literature and its applications [Electronic version]. International Journal of Science Education, 25 (9), 1049-1079. 
Pullella, P., \& Lewis, C. (2008). Vatican document denounces in vitro; Bioethics; Embryonic stem-cell research seen as immoral. World, A19.

Roth, W., \& Alexander, T. (1997). The interaction of students' scientific and religious discourses: Two case studies [Electronic version]. International Journal of Science Education, 19 (2), 125-146.

Simpson, D., \& Oliver, S. (1990). A summary of major influences on attitude toward and achievement in science among adolescent students. Science Education, 74, 1-18.

Talton, E. L., \& Simpson, R. D. (1985). Relationships between peer and individual attitudes toward science among adolescent students. Science Education, 69, 19-24.

Talton, E. L., \& Simpson, R. D. (1986). Relationship of attitudes toward self, family, and school with attitude toward science among adolescents. Science Education, 70, 365-374.

Taylor, P. (1993). Minority ethnic groups and gender access in higher education. New Community, 19, 425-440.

Tobin, K. (2010). Issues of our time: science, religion, and literacy [Electronic version]. Cultural Studies of Science Education, 5, 1-4.

Roth, W., \& Alexander, T. (1997). The interaction of students' scientific and religious discourses: two case studies [Electronic version]. International Journal of Science Education, 19 (2), 125-146.

Vygotsky, S. L. (1987). Thinking and speech. In R.W. Riber \& A.S. Carton (Eds.), The collected works of S.L. Vygotsky, Volume 1: Problems of general psychology. New York: Plenum.

Woodrow, D. (1996). Cultural inclinations towards studying science and mathematics. New Community, 22, 23-28.

Zacharia, Z., \& Barton, A. C. (2004). Urban middle-school students' attitudes toward a defined science [Electronic version]. Science Education, 88 (2), 197-222.

MedlinePlus, the US National Library of Medicine, National Institute of Health. Retrieved on April 9, 2015 from http://www.nlm.nih.gov/medlineplus/cloning.html

Received 01 February 2015; accepted 26 April 2015

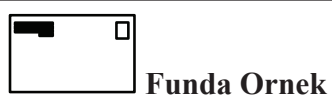

PhD., Kocaeli, Turkey.

E-mail: fundaornek@gmail.com 